DOI: $10.1515 /$ rpp-2015-0023

PhD in Pedagogical Sciences, Associate Professor, OLENA VOLIARSKA Ukrainian State Employment Training Institute, Ukraine Address: 17 Novovokzalnaya St., Kyiv, 03038, Ukraine

E-mail: esv6666@mail.ru

\title{
PROFESSIONAL TRAINING OF THE UNEMPLOYED: FOREIGN AND NATIVE TENDENCIES
}

\begin{abstract}
The article summarizes foreign and native tendencies in modern adult education. Their impact on the renovation of training the unemployed in Ukraine has been analyzed. It has been established that the system of adult training must meet the socio-economic, political and cultural changes in Ukraine. It has been indicated that defined tendencies should be considered when developing a strategy to modernize our system of training the unemployed. It has been pointed out that the organization and improvement of training the unemployed are caused by the interaction of three blocks: governance, social protection against unemployment, education market. Organized professional training in the employment sphere provides for developed infrastructure, which covers a range of organizations and agencies providing educational services and close cooperation of training with directions of socio-economic and educational policy. The role of the State Employment Service of Ukraine in professional training for the unemployed has been defined. Activities of specialists in professional training for adults is built according to the short-term and long-term forecasting and analytical-predictive control based on the world's economic, cultural and educational tendencies.

Based on the theoretical analysis of foreign and native scientists' works we have concluded that the main tendencies include proper educational tendencies and extra educational tendencies caused by global processes in the world, the problems of humanity, the growing role of education in the development of social consciousness in the professional development of modern competitive specialist

Key words: the unemployed, globalization, employment, information, adult education, professional education, professional training, tendencies.

\section{INTRODUCTION}

Ukraine has been constantly implementing principles to make its activities liberal for fulfilling every man's potential. At the same time, the role of the state has significantly been changed to ensure the effective employment policy. In fact, its functions have been reduced to create the conditions for the motivation of citizens in the randomly chosen areas of professional activities, which should be professionally trained for competitive and dynamic labour market.

The professional education of the population has become a priority in the system of national programmes against unemployment. This kind of education carries out the main function in creating the foundation of professional competence for a competitive specialist.

The development in professional education of Ukraine enables to expose the problems that are available today in the area of professional training the unemployed: between the modern concepts about professional training of unemployed specialists and traditional understanding of scientific and methodological support in the process of
\end{abstract}


increasing professional competence of aforementioned categories among the working population; between the elimination of stereotypes and changing attitudes to upgrading professional training.

\section{THE AIM OF THE STUDY}

The aim of the article is a theoretical generalization of modern tendencies in the field of adult education as a prerequisite for renewing professional training the unemployed in Ukraine.

\section{THEORETICAL FRAMEWORK AND RESEARCH METHODS}

The modern production requires the targeted specialist, so that systematic efforts have been made to eliminate the existing traditional stereotypes in the professional education and approaches have been aimed at enhancing professional competence.

Theoretical analysis in the works of J. Adams, J. Brunner, J. Dewey, M. Knowles allows noting that the professional training of adults in the USA is targeted at the traditional and innovative approaches to the formation of educational content (Knowles, 1989). The researcher of training the unemployed N. Bidyuk claimed that, according to the traditional approach, the main task of education is the development of mental abilities rather than acquisition of factual knowledge. The innovative approach based on the theory of the didactic utilitarianism, uses the priority of individual and social activity of the adult (Бідюк, 2008). Consequently, modern professional training of adults in the USA is realized on the basis of didactic utilitarianism theory.

Within the context of scientific understanding of the problems in the area of specialists' professional training, such works can be considered particularly valuable: the works of famous English scientists: R. Jones, S. Kerk, J. Lowe, A. Rogers. The scientific and pedagogical publications of international organizations such as the Council of Europe, UNESCO, the European network of information and documentation in the field of education, the British regulations (the parliamentary reports and recommendations to government commissions, legislative acts on issues of adult education, etc.), pedagogical publications in the UK and other foreign countries in the field of adults' professional training (Language Teaching (1996-2003), International Journal of Lifelong Education (1991-2006), International Journal of Teaching and Learning in Higher Education (20042006)) have shown that the functionally important interconnected components of the system of adult education in the UK are formal and informal education. As a result, after making the theoretical analysis of specialists' professional training, we have found the following principles of modern development of adults' professional training in the UK as the interaction of informal and formal education; the independence, decentralization, voluntary, access to all forms of training; orientation of teaching towards the formation of citizens' competence.

European Commission determined that the vast majority of European countries have a legal and regulatory framework for the settlement of Adult Education, outlining their purpose, principles and the mechanisms of state support, the main participants, their rights and duties, how to coordinate the actions of different providers of educational services, principles and financing schemes (European Commission, 2005).

Consideration and justification of these questions are in the works of national pedagogues (O. Dubasenyuk, S. Goncharenko, I. Ignatyuk, V. Kremen, A. Piehota etc.).

At the same time we have not found the works, which would have made research and got the solutions for the issues and tendencies of training the adult unemployed. Underestimating the orientation training content and advanced training of unemployed unfavourably affects the levels of their readiness for employment. This determines the need 
of attaching much attention to upgrade the providing system of professional training of the unemployed who are willing to increase their professional competence.

Main research method in studying the problem of current tendencies in adult education as a prerequisite for renewing and improving the professional training of the unemployed is a theoretical analysis of foreign and domestic scholars' works.

\section{RESULTS}

In the modern terms of the global labour market tendencies are appearing to change the professional training, professional development and the retraining of personnel potential in companies, organizations and institutions. In European countries the training of the adult working population, which can develop and implement innovations for high- and knowledge-intensive factories, is the main result of the modernization in the professional educational process (European Commission, 2005). Therefore, the system of adult professional training should not only adequately respond to socio-economic, political and cultural changes in Ukraine, but operate on the basis of short- and long-term forecasting and analytics-predictive management based on the world's economic, social, cultural and educational tendencies.

Summing up the different opinions of foreign and national scientists it is possible to distinguish two groups of major tendencies that determine the relevance and necessity of modernization in the national professional adults' training system:

$>\quad$ non-educational tendencies that are caused by global processes in the world and problems of humanity, the world's social and economic tendencies, socio-cultural and industrial situation at the national level. They include sharpening of competition for leadership, worsening global problems, the rate of scientific and technological progress, the dynamics of the labour market, the establishment of sovereign states, economic and political globalization, regionalization and decentralization;

$>$ educational tendencies that are defined by the modern tendencies of education development in the world and certain regions, increasing educational role in the development of social consciousness and society, especially the development of scientific research and educational institutions that fulfill their unique mission in promoting social and scientific progress. We believe these tendencies are mass character of higher professional education, transformation of education into the service sector, the computerization of the educational process, problem of recruiting highly qualified teachers.

It should be noted that the aforementioned tendencies must be considered when developing the strategy and techniques to modernize our professional training system of the unemployed.

Having accepted the abovementioned classification as a basis and completed it, we have singled out a group of extra educational tendencies as a subgroup of international tendencies. We believe they are putting forward new requirements for professional training of the unemployed in our country:

1. Increasing globalization that is associated with the irreversible free movement of the cultural and information flows of people, capital, resources and the universalization of scientific and technological progress. Globalization causes the process of interdependence (events, phenomena and processes occurring in the world) and formation of the world as a single system of interacting and interrelated states. Due to the development of information and communication technology, national boundaries created at the global level for communication, cooperation, dissemination of information and knowledge are getting blurred. It is formed by the global system of knowledge that unites different world cultures, covering economics and politics, science, education (Brunner, 2001). 
2. The transition to the information society where the economy is based on expanding global information system. The industrial revolution in the second half of the twentieth century marked the transition from industrial to post-industrial society. The level of socio-economic development of modern post-industrial countries more than agrarian and industrial societies of past centuries is determined due to spreading informatisation within society (Brunner, 2001). Besides, the transition to the information society entails fundamental changes in all spheres (political, social and educational).

3. Acceleration of the scientific and technological progress rate as well as expanding the global information system. In the dynamically changing world in terms of intensive development of science, industry, global spread of information and communication technologies, the time of scientific information renovation is reduced. This tendency, in our opinion, serves as the important basis for the recognition of professional education leading role in the XXI century. The prevalence of information and communication technology is the first condition for the development of enterprises, organizations and institutions, an essential tool for modernization, development and implementation of more efficient technologies to improve product quality, and as a result people's lives.

4. The economic, social and cultural regionalization. It is defined as the opposite tendency of globalization and is aimed at disintegration of large companies in order to maintain existing production relations, identity cultural spaces, national and cultural identity of the population on vast territories.

We believe that in this context of implementation of regional programmes on economic and socio-cultural development the role and impact of educational processes on scientific and technological, human resources provision of the region are increasing. In determining the ways and mechanisms for the modernization of national systems of professional education, the regional aspects of preparing adults to perform professional functions in the workplace must be taken into account.

Thus, the main capital of modern society is highly trained and technologically prepared qualified specialists who are ready to search and develop new information, formulate problems and take risks, develop and make innovation in the manufacturing and social sector. Thus, personal and public significance of professional training of the unemployed is emphasized. It should be noted that professional training is the mechanism of personality development, and the significant factor in the social and economic progress.

Along with the socio-cultural extra educational tendencies that are caused by global processes, we point out the tendencies that according to the prominent national scientists N. Nychkalo, L. Lukyanova, Yu. Marshavin, L. Sigayeva influence the development of adults' professional training in a particular country. Such tendencies typical for Ukraine are:

1. The formation of Ukraine as a sovereign state. For Ukraine and other former Soviet states of the CIS, Eastern Europe, the tasks of sovereign state construction characterized by socially-oriented market economy, the process of democratic and civil society formation put forward the new requirements and approaches to the social education of youth and adult education. From our perspective, the most important educational challenge serves forming, on the one hand, a citizen - a patriot of his/her country, on the other hand, a citizen of the world, without losing national roots and identity, who is able to realize their rights and responsibilities in accordance with universal values and moral and legal standards effective in a society. In this connection it is necessary to study new approaches to improve the educational process of the adult population, providing citizens 
with the acquisition of social experience through the development of social communication, legal literacy, information competence and so on.

2. The dynamics of the labour market in Ukraine, like in the most countries in Europe and the world, is a part of the global labour market which is enhanced by the objectively increasing need to use multinational qualified personnel.

3. The specificity of adults' training who have become unemployed. The economic situation of the country and modern market economy have led to the emergence of social phenomena - unemployment.

Within the limits of transformational changes in the labour market of Ukraine the organisation and improvement of the professional training system of the unemployed are caused by the interaction of three units: 1) a unit of public administration and adjustment by means of organizational measures (provision of employment of the working population, training and retraining of personnel); 2) a unit of social protection of population in case of unemployment (payment of unemployment benefits, benefits for low income groups, etc.); 3) power market of educational services (state and private institutions that can provide services of professional training). These elements of the organization are to enhance professional training of the unemployed taking into account the formation of conditions under which each individual is supposed to have a certain status in the social structure.

The researcher Yu. Marshavin notes that the effectiveness of professional training of the unemployed registered in the State Employment Office to a certain extent is determined by the evaluation system of its base and the regional offices, which is based on the following: determination of the most efficient organizational forms and methods of their attraction to professional training; selection of methods for the formulation of educational institutions for the implementation of training; the opening of employment centers which have achieved the highest efficiency in the training of the unemployed, for further study, synthesis and dissemination of their work experience; in order to stimulate educational institutions to improve the organization, forms, methods, means and training methods training the unemployed; to improve techniques and technologies of professional training in accordance with the requirements of employers (Маршавін, 2013)

It should be pointed out that the most rational way of training the unemployed is the formation of professional training system of the unemployed with the full support of state, regional, municipal and commercial structures. Consequently, the national employment system of the population is organized to provide the developed infrastructure which covers a range of organizations and agencies that provide the educational services and the close interaction with professional training directions of social, economic and educational policy.

\section{CONCLUSIONS}

So, we have theoretically analyzed the tendencies of adult education as a prerequisite for upgrading and improving the professional training the unemployed in Ukraine. We have compared the certain tendencies with our own education ones that are caused by global processes in the world, issues of humanity, the growing role of education in the development of social consciousness and professional formation of a contemporary competitive specialist.

In the future, we see the study of the effectiveness of professional training the unemployed in the European countries and in the conditions of training establishments within the system of the State Employment Service in Ukraine. 


\section{REFERENCES}

1. European Comission. (2005). Common European Principles for Teacher Competenciese and Qualifications. Retrieved 27.11.2014 from :

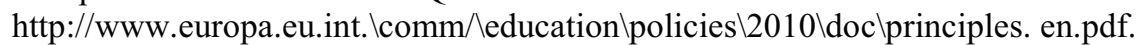

2. Knowles, M. (1989). The making of an adult educator: an autobiographical journey. San-Francisco : Jossey-Bass, p. 211.

3. Бідюк, Н. (2008). Особливості змісту та форм організації навчання безробітних фахівиів в системі освіти дорослих США [Features of the content and organization forms of training the unemployed in the adult education system of the USA]. Порівняльна професійна педагогіка [Comparative Professional Pedagogics], No 4, p. 284-293. (in Ukrainian).

4. Бруннер, Х. (2001). Глобализация, образование и револючия в технологии [The globalization, education and the revolution in technology]. Москва : Париж (in Russian).

5. Маршавін, Ю. (2013). Ефективність професійного навчання безробітних: методологія та інструментарій оцінювання [The effectiveness of professional training the unemployed: methodology and the evaluation instruments]. Ринок праиі та зайнятість населення [Labour Market and Employment], № 4, p. 6-11 (in Ukrainian). 